\title{
Bangkok 2005
}

\author{
By Brandon Wee
}

Fall 2005 Issue of KINEMA

\section{BANGKOK INTERNATIONAL FILM FESTIVAL 2005}

At the government-bankrolled Bangkok International Film Festival's third edition (13-20 January 2005), it should not have been surprising that nationalism would be a perceptible current in its Thai Panorama program. What made this particularly poignant was the festival's unfortunate coincidence with the aftermath of South Asia's devastating tsunami - customarily, a time occasioned by the need for solidarity, or at the very least, the appearance that national interests matter.

How are national interests articulated in Thai cinema? Certainly, they are not novel. Besides horror and transvestitism, Thai blockbusters have also been thematically marked by national pride and jingoism. The successes of Thanit Jitnukul's Bang Rajan (2000) and Chatrichalerm Yukol's 2001 Suriyothai are just two instances of period epics that chart Siamese solidarity and sacrifice against Burmese aggression. More recently, the martial arts gloss of Prachya Pinkaew's Ong-Bak (2003) largely eclipsed its portrayal of the Thai psyche.

Panna Rittikrai's Born To Fight (2004) pits a group of athletes against military insurgents plotting to nuke Bangkok, with gloriously insane stunts competing with outrageous attempts to incite patriotism. In Yongyoot Thongkongtoon's farcical Maid (2004), four country girls are persuaded to spy in the name of national duty with a racist subplot involving a Karen refugee. In Somching Srisupap's Sagai United (2004), an opportunistic referee enters a group of Sagai boys into the annual King's Cup soccer tournament after realising their dexterity, but the team's incentive to win is impressed by the belief that the trophy - the monarch personified - will save their fellow folk from a killer epidemic.

Strangely, Parkpoom Wongpoom's and Banjong Pisanthanakun's chartbuster The Shutter (2004) felt the least "Thai" of all, due to influence of Japanese horror. Best explained by its Thai title, translated as "press the camera's button and see a spirit", the fates of Ton and Jane are sealed when they run over a figure and flee. A photographer, Ton soon discovers that not only do all his photographs start manifesting a diabolical presence, but that his buddies are also killing themselves in succession. The film's lack of subtlety does not lessen its impact, the success of which owes much to exploring new grounds within the genre.

The program's most attractive film, Wisit Sasanatieng's Citizen Dog (2004) fondly recalls the iridescence of Tears of the Black Tiger (2000). Here, Bangkok is visualised as a literal daydream to counter the metropolitan nightmare it really is. The story follows an established convention of a country boy who experiences dislocation in the city, except that here, it is rendered as fantasy. Pod leaves his agricultural abode for Bangkok and falls for Jin, a mania-ridden maid, but she is instead fixated on a hippy whom she misconstrues as a vanguard for environmental activism and who nonetheless inspires her crusade against plastic bottles. As beguiling as Citizen Dog's visuals are, its control of characters is unfortunately a meandering mess, in sharp contrast to its savvy imagery.

A more revealing thread of nationalism was present in the four-film retrospective of Vichit Kounavudhi (19221997): First Wife (1978), Mountain People (1979), Son of the Northeast (1982), and Her Name is Boonrod (1985). A writer-filmmaker, Vichit contributed short stories for the print media before becoming a journalist and novelist. He started in motion pictures through acting, followed by screenwriting, directing and editing. His early films dealt with domesticity, whereas later ones were documentary-like, as evidenced in Mountain People and Son of the Northeast - both fascinating insights to the ethnic communities of Northern Thailand.

Mountain People opens with a narrator introducing some of Indochina's indigenous groups by describing their traits and temperaments, though without neutrality. The ensuing story is both an adventure and coming-of-age rite that a young Egaw couple must undertake. After the girl gives birth to twins, an elder decrees the offsprings are the devil's work and orders the fetuses killed and the parents exiled for a year. The deed is carried out and the saddened couple is put on their way, where much of their voyage across a treacherous topography is the basis upon which a love story develops. 
Similarly, Son of the Northeast exalts the values and solidarity of the people of Isan, a scorching and arid region in Thailand's northeast. Centring on the way of life of agrarians who must overcome a drought by journeying to the nearest oasis, Vichit illustrates the quirks that make life interesting for these folks, such as the endless spats between Chinese and Vietnamese immigrants which are played out to the amusement of the Thais. Unfolding in an otherwise subdued tone, the film's most rousing sequence showcases a mongoose hunt which, while both exhilarating and amusing, also doubles as a lesson on loyalty and gratitude.

Although Vichit's films are imbued with nationalist strands, they have been long neglected in their native land. As with Ratana Pestonji last year, the conferral of a Lifetime Achievement Award on Vichit was ironic. Of the more than forty films he made, about ten remain. On account of this staggering loss, coupled with the want of literature on him, the festival's praise of "a master of the Thai motion picture industry" certainly risks losing its clout.

\section{References}

\section{GOLDEN KINNAREE AWARDS}

Best Film: The Sea Inside (Alejandro Amenábar; Spain-France-Italy 2004)

Best Director (ex aequo): Christophe Barratier for Les Choristes (France-Switzerland-Germany 2004) and Park Chan-wook for OldBoy (South Korea 2003)

Best Actor: Javier Bardem in The Sea Inside (Alejandro Amenábar; Spain-France-Italy 2004)

Best Actress (ex aequo): Annette Bening in Being Julia (István Szabó; Canada-USA-Hungary-UK 2004) and Ana Geislerová in Želary (Ondřej Trojan; Czech Republic 2003)

Best ASEAN Film: The Beautiful Washing Machine (James Lee; Malaysia 2004)

Jameson Best ASEAN Short Film: Birthday (Bertrand Lee; Singapore 2004)

Special Mentions: Gay or Not (Wai Yee Chan and Yee Nam Lou; Hong Kong 2004); Little Terrorist (Ashvin Kumar; India 2004); Down The River (Anucha Boonyawatana; Thailand 2004); Cut (Royston Tan; Singapore 2004)

Best Documentary: Born Into Brothels (Zana Briski and Ross Kauffman; India-USA 2004)

Special Mentions: Touch The Sound (Thomas Riedelsheimer; Germany-UK 2004), for giving inspiration through sound and artistic treatment; and Final Solution (Rakesh Sharma; India 2003), for the courage of reflecting realities.

New Voices Award: Bharatbala for Hari Om (India 2004)

Lifetime Achievement Award: Vichit Kounavudhi (Thailand)

Career Achievement Award: Joel Schumacher (USA)

Crystal Lens Award: Rodrigo Prieto (Mexico)

\section{Author Information}

Brandon WEE lives in Toronto. He has written for Asia Pacific Arts (Los Angeles), Cineaste (New York), Cinema Scope (Toronto), Ricepaper (Vancouver), and Senses of Cinema (Melbourne). 